\title{
Seroprevalence and risk factors associated with Neospora caninum in commercial sheep from northwest of Rio Grande do Sul, Brazil
}

\section{Soroprevalência e fatores de risco associados a Neospora caninum em ovinos comerciais do noroeste do Rio Grande do Sul, Brasil}

\author{
Angélica Consalter ${ }^{*}$; Andressa Ferreira da Silva ${ }^{2}$; Vinicius Grangeia Gaia ${ }^{3}$; Eraldo \\ Lourenso Zanella ${ }^{4}$; Guilherme Nunes de Souza ${ }^{5}$; Ana Maria Reis Ferreira ${ }^{6}$
}

\section{Highlights:}

Neosporosis was detected in $20.3 \%$ of sheep flocks.

All flocks sampled had seropositive animals.

Sheep breeds $>1$ year of age demonstrated a higher risk for infection by Neospora caninum.

\begin{abstract}
Neospora caninum is a widely distributed parasite, which significantly impacts reproduction in ruminants. This study aimed to survey the seroprevalence and risk factors associated with neosporosis infection in commercial herds of sheep in the northwest of Rio Grande do Sul, Brazil. Three hundred sheep serum samples were used to investigate anti- $N$. caninum antibodies using indirect immunofluorescence reaction at a 1:40 dilution. The presence of anti- $N$. caninum antibodies was detected in $20.3 \%(61 / 300)$ of the samples evaluated; however, positive reactions were observed in all (13/13) flocks sampled. Sheep breeds $>1$ year of age had 1.2-fold higher risk for infection with $N$. caninum (odds ratio 2.2 [95\% confidence interval 1-5.1]; $\mathrm{P}<0.001$ ). These findings should raise awareness on the importance of serological screening, identification of risk factors, and maintenance of preventive measures, such as not allowing dogs to contact sheep feed and not offering the placental remains of ruminants to canids.
\end{abstract}

Key words: Neosporosis. RIFI. Serology. Sheep.

\section{Resumo}

Neospora caninum é um parasita amplamente distribuído e de grande importância para a reprodução de ruminantes. O objetivo deste estudo foi realizar um levantamento da soroprevalência e dos fatores de risco associados à neosporose em rebanhos comerciais de ovinos no noroeste do Rio Grande do Sul. Foram utilizadas 300 amostras de soro de ovelhas para investigar anti- $N$. caninum por Reação de Imunofluorescência Indireta (IFAT) com uma

\footnotetext{
${ }_{1}$ Discente de Doutorado, Pós-Graduação em Clínica e Reprodução Animal, Universidade Federal Fluminense, UFF, Niterói, RJ, Brasil. E-mail: angelicaconsalter@gmail.com

2 Profa, Departamento de Medicina e Cirurgia Veterinaria, Universidade Federal Rural do Rio de Janeiro, UFRRJ, Brasil. E-mail: mvandressa@yahoo.com.br

3 Discente de Mestrado, Programa de Pós-Graduação em Medicina Veterinária, Patologia e Ciências Clínicas, UFRRJ. E-mail: vinicius.g.gaia2@gmail.com

4 Prof., Laboratório de Reprodução e Melhoramento Genético Animal, Universidade de Passo Fundo, UPF, Passo Fundo, RS, Brasil. E-mail: ezanella@upf.br

5 Pesquisador, Empresa Brasileira de Pesquisa e Agropecuária, Embrapa Gado de Leite, Juiz de Fora, MG, Brasil. E-mail: guilherme.souza@embrapa.br

6 Profa, Departamento de Patologia e Clínica Veterinária, UFF, Brasil. E-mail: ana_ferreira@id.uff.br

* Author for correspondence
} 
diluição de 1:40. A presença de anticorpos anti-N. caninum foi detectada em $20.3 \%(61 / 300)$ das amostras avaliadas. Reações positivas foram observadas em todos (13/13) os rebanhos amostrados. Ovinos com mais de um ano tiveram 1.2 mais chances de serem infectados por $N$. caninum (odds ratio 2.2, intervalo de confiança 1-5.1) $(\mathrm{P}<0.001)$. Com esses dados, chamamos atenção para a importância da triagem sorológica, identificação de fatores de risco e manutenção de medidas de prevalência, como não permitir que os cães entrem em contato com a alimentação das ovelhas e não oferecer os restos placentários dos ruminantes aos canídeos.

Palavras-chave: Neosporose. RIFI. Sorologia. Ovinos.

Neospora caninum is a protozoan belonging to the phylum Apicomplexa, family Sarcocystidae and subfamily Toxoplasmatinae, and morphologically similar to Toxoplasma gondii, but biologically different (Cerqueira-Cézar et al., 2017; J. P. Dubey et al., 2002). Neosporosis is primarily disease of cattle, causing abortion in the species, while toxoplasmosis is a serious disease in humans, sheep, and many other warm-blooded animals ( J. P. Dubey \& Schares, 2011).

The transmission of $N$. caninum to intermediate hosts occurs through the ingestion of oocysts eliminated in the environment, and bradyzoites present in tissue cysts and transplacentally ( $\mathrm{J}$. P. Dubey et al., 2002; Filho et al., 2017). Canids (domestic and wild canids, dogs, coyote, and wolf) are essential for transmission of $N$. caninum, because they are the final hosts of the parasite, and they pose a risk to sheep (Cerqueira-Cézar et al., 2017; Wang et al., 2018) In addition, grazing dogs are used to assist in handling and frequently come into contact with sheep.

Neospora caninum infection can lead to spontaneous abortion or the birth of weakened lambs (Moreno et al., 2012; Razmi \& Naseri, 2017). Its prevalence in Brazilian herds ranges from $8 \%$ in São Paulo (Machado, Kikuti, Langoni, \& Paes, 2011) to $39.8 \%$ in Sergipe (H. Rizzo et al., 2017). However, its clinical and economic impact on sheep is not fully understood, with few, if any, published studies in the surveyed region. As such, the objective of this study was to characterize the epidemiological importance of $N$. caninum infection in commercial sheep flocks in the northwest of Rio Grande do Sul by surveying the seroprevalence and risk factors associated with neosporosis.

The minimum sample size required for this study was calculated using EpiInfo 7.1.5 (Centers for Disease Control and Prevention [CDC], 2002), using $16.3 \%$ (Ferreira et al., 2016) as the expected prevalence, with a margin of error of $5 \%$, and a confidence interval of $95 \%$. Given an estimated total population of 327.828 sheep in the region studied according to data from the Instituto Brasileiro de Geografia e Estatística [IBGE] (2014), a minimum sample size of 224 was required.

A cross-sectional study was performed using blood samples from 300 sheep, both female and male ( $\geq 1$ year of age), in 10 municipalities from 13 rural properties (Table1) in the northwest region of Rio Grande do Sul to perform serological tests for anti- $N$. caninum antibodies. Blood samples were collected by venipuncture of the jugular vein in $10 \mathrm{~mL}$ tubes (Vacutainer, BD Biosciences, Franklin Lanes, NJ, USA) without anticoagulant, then conditioned in an isothermal container at $5^{\circ} \mathrm{C}$, and centrifugated at $1000 \times g$ for $10 \mathrm{~min}$. Sera were stored in microtubes at $-20^{\circ} \mathrm{C}$.

An individual survey of sheep characteristics was recorded including sex, age, and breed. In addition, farmers answered questionnaires surveying specific topics about the flock, including: location; purpose and type of the holding; sheep contact with other animals; water source(s); water supply; food location; veterinary care; presence of dogs on the property; and presence of poor fetal formation and abortion in the past 12 months. 
Table 1

Seroprevalence of antibodies anti-Neospora caninum in sheep from northwestern Rio Grande do Sul State, Brazil

\begin{tabular}{cccc}
\hline Municipalities & Farm no. & $\mathbf{n}$ & $\mathbf{\%}$ Pos. \\
Passo Fundo & 1 & 30 & 3.3 \\
Vila Maria & 2 & 30 & 16.6 \\
Marau & 3 & 21 & 23.8 \\
Nova Araça & 4 & 20 & 15.0 \\
Nova Bassano & 5 & 20 & 45.0 \\
Soledade & 6 & 26 & 19.2 \\
Guaporé & 7 & 23 & 26.0 \\
Erechim & 8 & 23 & 17.3 \\
Erechim & 9 & 20 & 25.0 \\
Gaurama & 10 & 20 & 20.0 \\
Erechim & 11 & 20 & 30.0 \\
Cruz Alta & 12 & 27 & 14.8 \\
Passo Fundo & 13 & 20 & 20.0 \\
\hline
\end{tabular}

Serum samples were diluted 1:40 in phosphate buffered saline (PBS, pH 7.2) and prepared according to manufacturer's instructions (Imunoteste ${ }$, Neospora caninum [IFAT], Ovino, Imunodot, Jaboticabal, SP, Brazil). After incubation in a humid chamber at $37^{\circ} \mathrm{C}$ for $30 \mathrm{~min}$, the samples and the positive and negative control were washed three times with PBS and dried for $5 \mathrm{~min}$. The antisheep immunoglobulin $\mathrm{G}$ was conjugate, prepared with Evans blue solution, was added and incubated again for an additional $30 \mathrm{~min}$ in a darkroom in an oven at $37^{\circ} \mathrm{C}$. After further washing with PBS solution, the slides were assembled and observed using a fluorescence microscope (Axio Lab.A1, Carl Zeiss GmbH, Jena, Germany) equipped with a $40 \times$ objective. Samples were positive when they demonstrated clear fluorescence.

The protocols performed in this study were approved by the Animal Use Ethics Committee of the Fluminense Federal University under protocol number 832 and by the University of Passo Fundo under protocol number 035 .
Independent or explanatory variables, obtained from the epidemiological questionnaires, of possible risk factors associated with seropositivity for antibodies to anti- $N$. caninum were selected based on frequency distribution after analysis using the chi-squared test, with the threshold for statistical significance set at $\mathrm{P}<0.05$. Variables that met the significance level were tested together in the forward conditional regression model.

Neospora caninum can lead to abortion or the birth of weakened lambs (Moreno et al., 2012; Razmi \& Naseri, 2017), however, transplacental transmission of this parasite in naturally infected small ruminants has been observed in Brazil (Nunes et al., 2017). The presence of anti- $N$. caninum was detected in $20.3 \%(61 / 300)$ of sheep and in all $(13 / 13)$ flocks sampled in the northwest of Rio Grande do Sul. This state has the largest commercial flock of sheep in Brazil (IBGE, 2014), thus research investigating the health status of these animals essential. Moreover, few studies involving sheep have been performed. 
Over the span of a decade, researchers found a prevalence of $3.2 \%(2 / 62)$ in sheep sampled from Rio Grande do Sul state (Vogel, Arenhart, \& Bauermann, 2006) and a recent study reported a seroprevalence of $16.3 \%$ (49/300) in ovine (Ferreira et al., 2016). However, a study by Ferreira et al. (2016) included only one city, Bossoroca, where only 30 sheep samples were collected from this region. Vogel et al. (2006), collected only 22 sheep samples from the city of Jóia, also in the northwest of the state. Thus, it is necessary to conduct research with consolidated sampling of each region.

In other Brazilian states, such as São Paulo, Rio de Janeiro and Maranhão, the prevalence was $8 \%$, $6.2 \%$, and $18.7 \%$, respectively (Cosendey et al.,
2018; Machado et al., 2011; Moraes et al., 2011). Despite the low prevalence reported in the State of São Paulo, investigators described the association of seropositivity with the presence of reproductive problems such as abortion, stillbirths and recurrent estrus (Machado et al., 2011). However, there was no such association found in this study, as shown in Table 2. However, it is possible that bias may have been introduced in the questionnaire answers from the producers regarding reproductive data because tabulation of these data on the property is often absent or inadequate, thus making it difficult to report on the period in which the changes occurred. The failure to identify a common starting time for illness may also have led to bias (Choi \& Pak, 2004).

Table 2

Frequency and association of Neospora caninum antibodies in sheep from northwestern Rio Grande do Sul, Brazil

\begin{tabular}{|c|c|c|c|c|c|c|}
\hline \multirow{2}{*}{ Variable } & \multirow{2}{*}{ Category } & \multicolumn{2}{|c|}{ Negative } & \multicolumn{2}{|c|}{ Positive } & \multirow{2}{*}{$\mathbf{P}$} \\
\hline & & $\mathbf{n}$ & $\%$ & $\mathbf{n}$ & $\%$ & \\
\hline \multirow[t]{2}{*}{ Gender } & Male & 45 & 80.4 & 11 & 19.6 & 0.887 \\
\hline & Female & 194 & 79.5 & 50 & 20.5 & \\
\hline \multirow{2}{*}{ Breeder } & $>1$ & 176 & 77.2 & 52 & 22.8 & 0.058 \\
\hline & $<1$ & 63 & 87.5 & 9 & 12.5 & \\
\hline \multirow[t]{3}{*}{ Age } & 1 & 63 & 87.5 & 9 & 12.5 & 0.164 \\
\hline & 2 & 46 & 78.0 & 13 & 22.0 & \\
\hline & $\geq 3$ & 130 & 76.9 & 39 & 23.1 & \\
\hline \multirow[t]{5}{*}{ Breed } & Dorper & 97 & 82.9 & 20 & 17.1 & 0.265 \\
\hline & Lacaune & & & & & \\
\hline & Pool Dorset,Suffolk & & & & & \\
\hline & Mixed breed & & & & & \\
\hline & Texel & 142 & 77.6 & 41 & 22.4 & \\
\hline \multirow[t]{3}{*}{ Production objective } & Genetics & 104 & 83.9 & 20 & 16.1 & 0.207 \\
\hline & Meat & 39 & 81.3 & 9 & 18.8 & \\
\hline & Mixed & 96 & 75.0 & 32 & 25.0 & \\
\hline
\end{tabular}


continuation

Production system

Consortium with other animal

Water source

Water supply

Food supply

Veterinary care

Presence of dogs

Fetal malformation in the last 12 months

Abortion in the last 12 months
Intensive

Semi-intensive

Yes

No

Mixed

Cistern

Artesian well

Weir

Reservoir inside

Reservoir outside

Direct from the source

Mixed

Reservoir inside
Reservoir outside
Mixed
Absent

Yes

Not

Yes

Not

Yes

Not

27

222

17

79.3

85.0

67.5

166

79.0

76.7

51

23.3

14.8

96.

79.2

79.6

80.0

57

4

$\begin{array}{cc}58 & 20.7 \\ 3 & 15.0\end{array}$

3.3

20.8

20.4

0.616

20.0

Yes

Not

$\begin{array}{lllll}137 & 81.5 & 31 & 18.5 & 0.361 \\ 102 & 77.3 & 30 & 22.7 & \end{array}$

\footnotetext{
* Significance level of $\mathrm{P}<0.05$.
}

In the state of Sergipe, a prevalence (39.8\%) higher than that found in this study was observed; associated risk factors included water source, absence of quarantine, and the presence of dogs and wild animals (H. Rizzo et al., 2017). These results were possibly due most likely to exposure to food or water contaminated with $N$. caninum oocysts eliminated by dogs. We could not assess the influence of dogs on sheep seropositivity because they were present on all farms. It is important to note that most herding dogs had access to placenta, aborted lambs, and fetal membranes of ruminants in this study. Such management failures may lead to continued exposure of the animals to $N$. caninum (Munhoz et al., 2010). 
Compared with other countries in the world, the lowest prevalence was in New Zealand (0.6\%), Argentina (1.54\%), China (8.4) and Costa Rica (10.9\%) (Hecker et al., 2018; Nie et al., 2018; Reichel, Ross, \& McAllister, 2008; Villagra-Blanco et al., 2019). Accordingly, Cerqueira-Cézar et al. (2017) more serological studies for $N$. caninum infection in animals have been conducted in Brazil than the rest of the world, however, these results are not comparable due to differences in serological tests, cut-offs, and antigens used.

Sheep breeds $>1$ year of age had a 1.2-fold (odds ratio 2.2 [95\% confidence interval 1-5.1]) $(\mathrm{P}<0.001)$ higher risk for infection with $N$. caninum according to the Nagelkerke coefficient $\left(\mathrm{R}^{2}=0.050\right)$ and Hosmer-Lemeshow test for model fit $(\mathrm{P}=0.764)$. These figures agree with those reported in the study by Cosendey et al. (2018) in which rates appeared to increase as lambs aged, which is due to continuous exposure to environments contaminated by oocysts. Furthermore, our data draw attention to breeding sheep because vertical transmission can occur in this species (Filho et al., 2017).

The seroprevalence of $N$. caninum in male was significantly higher than in female in Tibetan Sheep from China (Nie et al., 2018), which is contrary to data reported by Rizzo et al., 2018 who found a higher prevalence in female sheep from São Paulo state; however, but we did not find such an association in the present study (Table 2). Other authors also did not find an association with sex (Faria et al., 2010; Salaberry et al., 2010).

Bovine neosporosis is an important cause of abortion in the south of the country (L. G. Corbellini, Driemeier, Cruz, Gondim, \& Wald, 2002; L. G. Corbellini et al., 2006), and the association of $N$. caninum infection in cattle was found on farms in Rio Grande do Sul, which had dogs close to the herd (L. G. Corbellini et al., 2006). On properties where sheep are reared together with cattle, sheep may be eventually participated in the epidemiology of infection (Vogel et al., 2006). Although there was no association between the prevalence of $N$. caninum in sheep and the association with other species, such as bovine, the importance of this factor is, nevertheless, recognized (Moura et al., 2014).

Additional factors associated with neosporosis in sheep include water source(s), absence of quarantine, and farm size and system of production (Faria et al., 2010; Rizzo et al., 2017). Compared with previous studies, no association was found among these variables. A study performed with herds in the municipality of Gravatá/PE, observed that in intensive regimens, the indices increased due to the higher concentration of animals exposed to contaminated food (Souza et al., 2009). Therefore, it is recommended to avoid contact of dogs with the ruminant feed and carry out periodic controls of rodents in order to reduce the risk of infection by $N$. caninum (McAllister et al., 1998).

Although neosporosis was detected in $20.3 \%$ of sheep flocks from the northwestern mesoregion of Rio Grande do Sul, all flocks sampled had seropositive animals. Sheep breeds $>1$ year of age exhibited a higher risk for infection with $N$. caninum. Data from this study should raise awareness on the importance of serological screening, identification of risk factors, and the maintenance of preventive measures, such as not allowing dogs to contact sheep feed and not offering the placental remains of ruminants to canids.

\section{Acknowledgements}

This study was financed in part by the Coordenação de Aperfeiçoamento de Pessoal de Nível Superior - Brasil (CAPES) - Finance Code 001 and FAPERJ- Fundação de Amparo à Pesquisa do Estado do Rio de Janeiro. The authors would like to give special thanks to the all farmers and to Rogério Nadal, Veterinarian of Universidade de Passo Fundo, for their collaboration in this study. 


\section{References}

Centers for Disease Control and Prevention. (2002). EpiInfo 7.1.5. Atlanta. CDC. Recuperado de https:// wwwn.cdc.gov/epiinfo/html/downloads.htm

Cerqueira-Cézar, C. K., Calero-Bernal, R., Dubey, J. P., Gennari, S. M., Cerqueira-Cézar, C. K., Calero-Bernal, R.,... Gennari, S. M. (2017). All about neosporosis in Brazil. Revista Brasileira de Parasitologia Veterinária, 26(3), 253-279. doi: 10.1590/s1984-29612017045

Choi, B. C. K., \& Pak, A. W. P. A. (2004). Catalog of biases in questionnaires. Preventing Chronic Disease, 2(1), 1-13. Recuperado de https://www. ncbi.nlm.nih.gov/pmc/articles/PMC1323316/

Corbellini, L. G., Driemeier, D., Cruz, C. F. E., Gondim, L. F. P., \& Wald, V. (2002). Neosporosis as a cause of abortion in dairy cattle in Rio Grande do Sul, southern Brazil. Veterinary Parasitology, 103(3), 195-202. doi: 10.1016/S0304-4017(01)00600-8

Corbellini, L. G., Pescador, C. A., Frantz, F., Wunder, E., Steffen, D., Smith, D. R., \& Driemeier, D. (2006). Diagnostic survey of bovine abortion with special reference to Neospora caninum infection: Importance, repeated abortion and concurrent infection in aborted fetuses in Southern Brazil. The Veterinary Journal, 172(1), 114-120. doi: 10.1016/j. tvj1.2005.03.006

Cosendey, R. I. J., Oliveira, F. C. R. de, Frazão-Teixeira, E., Souza, G. N. de, Brandão, F. Z., Ferreira, A. M. R., \& Lilenbaum, W. (2018). Seroprevalence of anti-Neospora caninum antibodies in sheep from the rapidly expanding flock of Rio de Janeiro, Brazil. Veterinary Parasitology: Regional Studies and Reports, 14(10), 59-62. doi: 10.1016/j. vprsr.2018.09.001

Dubey, J. P., Barr, B. C., Barta, J. R., Bjerkås, I., Björkman, C., Blagburn, B. L.,... Lindsay, D. S. (2002). Redescription of Neospora caninum and its differentiation from related coccidia. International Journal for Parasitology, 32(8), 929-946. doi: 10.1016/S0020-7519(02)00094-2

Dubey, J. P., \& Schares, G. (2011). Neosporosis in animals the last five years. Veterinary Parasitology, 180(1-2), 90-108. doi: 10.1016/j.vetpar.2011.05.031

Faria, E. B., Cavalcanti, E. F. T. S. F., Medeiros, E. S., Pinheiro, J. W., Jr., Azevedo, S. S., Athayde, A. C. R., \& Mota, R. A. (2010). Risk factors associated with Neospora caninum seropositivity in sheep from the State of Alagoas, in the Northeast Region of
Brazil. Journal of Parasitology, 96(1), 197-199. doi: 10.1645/GE-2176.1

Ferreira, M. S. T., Vogel, F. S. F., Sangioni, L. A., Cezar, A. S., \& Menezes, F. R. de. (2016). Neospora spp. and Toxoplasma gondii infection in sheep flocks from Rio Grande do Sul, Brazil. Semina: Ciências Agrárias, 37(3), 1397-1406. doi: não tem

Filho, P. C. G. A., Oliveira, J. M. B., Andrade, M. R., Silva, J. G., Kim, P. C. P., Almeida, J. C., Mota, R. A. (2017). Incidence and vertical transmission rate of Neospora caninum in sheep. Comparative Immunology, Microbiology and Infectious Diseases, 52(4), 19-22. doi: 10.1016/j.cimid.2017.05.006 Corrigir o nome do autor: FILHO não é sobrenome. Corrigir a citação no texto- Resposta: no artigo está como sobrenome e citação sugerida Filho et al.

Hecker, Y. P., Masson, F. M., Armendano, J. I., Cora, J., Olivares, C. F., Gual, I., Cantón, G. J. (2018). Evaluation of frequency of antibodies against Toxoplasma gondii, Neospora caninum and Sarcocystis spp. and transmission routes in sheep from Humid Pampa, Argentina. Acta Parasitológica, 63(2), 416-421. doi: 10.1515/ap-2018-0048

Instituto Brasileiro de Geografia e Estatística. (2014). Efetivo do rebanho de ovinos em 2014. Brasília, IBGE. Recuperado de http://www.ibge.gov.br/home/

Machado, G. P., Kikuti, M., Langoni, H., \& Paes, A. C (2011). Seroprevalence and risk factors associated with neosporosis in sheep and dogs from farms. Veterinary Parasitology, 182(2-4), 356-358. doi: 10.1016/j.vetpar.2011.05.021

McAllister, M. M., Dubey, J. P., Lindsay, D. S., Jolley, W. R., Wills, R. A., McGuire, A. M. (1998). Dogs are definitive hosts of Neospora caninum. International journal for parasitology. 28(9), 1473-1478. doi: https://doi.org/10.1016/S0020-7519(98)00138-6

Moraes, L. M. de B., Raimundo, J. M., Guimarães, A., Santos, H. A., Macedo, G. L., Jr., Lima, G. de,... Baldani, C. D. (2011). Occurrence of antiNeospora caninum and anti-Toxoplasma gondii IgG antibodies in goats and sheep in western Maranhão, Brazil. Revista Brasileira de Parasitologia Veterinária, 20(4), 312-317. doi: 10.1590/S198429612011000400010

Moreno, B., Collantes-Fernández, E., Villa, A., Navarro, A., Regidor-Cerrillo, J., \& Ortega-Mora, L. M. (2012). Occurrence of Neospora caninum and Toxoplasma gondii infections in ovine and caprine abortions. Veterinary Parasitology, 187(1-2), 312318. doi: 10.1016/j.vetpar.2011.12.034 
Moura, A. B. de, Güths, M. F., Farias, J. A., Souza, A. P. de, Sartor, A. A., \& Quadros, R. M. de. (2014). Neospora caninum seroprevalence and risk factors for ewes from Santa Catarina Plateau, Brazil. Semina: Ciências Agrárias, 35(5), 2591-2600. doi: 10.5433/1679-0359.2014v35n5p2591

Munhoz, K. F., Luca, M., Neto, Santos, S., M. A., Garcia, J. L., Guimaraes Junior, J. S., Vidotto, O.,... Yamamura, M. H. (2010). Occurrence of antiNeospora caninum antibodies in sheep from farms located in northern Paraná, Brazil. Semina: Ciências Agrárias, 31(4), 1031-1039. doi: Não tem

Nie, L.-B., Cong, W., Zou, Y., Zhou, D.-H., Liang, Q.L., Zheng, W.-B.,... Zhu, X.-Q. (2018). First report of seroprevalence and risk factors of Neospora caninum infection in tibetan sheep in China. BioMed research international, 2018(1), 1-4. doi: $10.1155 / 2018 / 2098908$

Nunes, A. C. B. T., Yamasaki, E. M., Kim, P. C. P., Melo, R. P. B., Ribeiro-Andrade, M., Porto, W. J. N., Mota, R. A. (2017). Transplacental transmission of Neospora caninum in naturally infected small ruminants from northeastern Brazil. Pesquisa Veterinária Brasileira, 37(9), 921-925. https://doi. org/10.1590/s0100-736x2017000900004

Razmi, G., \& Naseri, Z. (2017). Molecular detection of Neospora caninum infection in ovine aborted foetuses in the Mashhad area, Iran. Annals of parasitology, 63(1), 45-47. doi: nome da Revista por extenso.

Reichel, M. P., Ross, G. P., \& McAllister, M. M. (2008). Evaluation of an enzyme-linked immunosorbent assay for the serological diagnosis of Neospora caninum infection in sheep and determination of the apparent prevalence of infection in New Zealand. Veterinary Parasitology, 151(2-4), 323-326. doi: 10.1016/j.vetpar.2007.11.002

Rizzo, H., Jesus, T. K. S. de, Gaeta, N. C., Carvalho, J. S., Pinheiro, J. W., Jr., Gregory, L., \& Villalobos, E. M. C. (2017). Pesquisa de anticorpos IgG para Neospora caninum e avaliação dos fatores de risco em ovinos do Estado de Sergipe. Pesquisa Veterinária Brasileira, 37(8), 813-819. doi: 10.1590/ s0100-736x2017000800006
Rizzo, H., Villalobos, E. M. C., Meira, E. B. S., Jr., Marques, E. C., Beraldi, F., \& Gregory, L. (2018). Ocorrência de anticorpos anti-Toxoplasma gondii e anti-Neospora caninum em ovinos com distúrbios reprodutivos e fatores de risco. Pesquisa Veterinária Brasileira, 38(2), 1317-1326. doi: 10.1590/16785150-pvb-4174

Salaberry, S. R. S., Okuda, L. H., Nassar, A. F. de C., Castro, J. R. de, \& Lima-Ribeiro, A. M. C. (2010). Prevalence of Neospora caninum antibodies in sheep flocks of Uberlândia county, MG. Revista Brasileira de Parasitologia Veterinária, 19(3), 148-151. doi: 10.1590/S1984-29612010000300004

Souza, O. L., Neto, Albuquerque, P. P. F., Santos, A. S., Fernandes, E. F. T. S., Faria, E. B., Moraes, E. P. B. X., . . . Mota, R. A. (2009). Prevalência de anticorpos IgG anti-Neospora caninum e fatores de risco associados à infecção em ovinos no município de Gravatá, Pernambuco, Brasil. Anais Jornada de Ensino, Pesquisa e Extensão (JEPEX), Recife, PE, Brasil. 9.

Villagra-Blanco, R., Barrantes-Granados, O., MonteroCaballero, D., Romero-Zúñiga, J. J., \& Dolz, G. (2019). Seroprevalence of Toxoplasma gondii and Neospora caninum infections and associated factors in sheep from Costa Rica. Parasite Epidemiology and Control, 4(10), e00085. doi: 10.1016/j.parepi.2019. $\mathrm{e} 00085$

Vogel, F. S. F., Arenhart, S., \& Bauermann, F. V. (2006). Antibodies to Neospora caninum in cattle, sheep and water buffalo in Rio Grande do Sul state, Brazil. Ciência Rural, 36(4), 1948-1951. doi: 10.1590/ S0103-84782006000600048

Wang, S., Li, L., Lu, Y., Zhang, H., Xie, Q., \& Zhang, Z. (2018). Seroprevalence and risk factors of Neospora caninum infection among domestic sheep in Henan province, central China. Parasite, 25(15), 1-5. doi: $10.1051 /$ parasite/2018019 